DOI: $10.19195 / 2082-8322.15 .3$

MONIKA ZIÓtKOWSKA

ORCID: 0000-0002-6243-5961

UNIWERSYTET JAGIELLOŃSKI

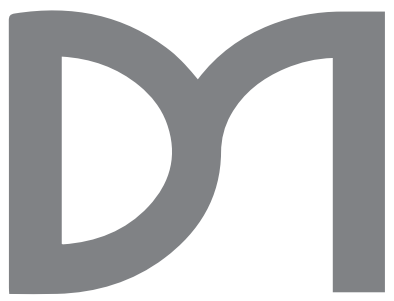

\title{
BOLERO, BEBOP I „BAL NAD BALE” \\ CZYLI TANECZNE METAFORY W WYBRANYCH TEKSTACH PIOSENEK AGNIESZKI OSIECKIEJ
}

\author{
Bolero, waltz and 'a ball of all balls' - dance metaphors \\ in selected song lyrics by Agnieszka Osiecka
}

\section{Summary}

The article is an analysis of selected lyrics from Agnieszka Osiecka's songs based on the theme of dance as a metaphor. The author of Sopockie bolero, To nasze sopockie bolero and Niech żyje bal uses dance as a lyrical situation which allows the author to analyze the lyrical l's intensified emotions. Osiecka also uses the possibilities provided by the song form - rhythmicity, repetitions, the closeness of the language of the song to the language of choreography.

Keywords: Agnieszka Osiecka, song, dance, bolero, ball, danse macabre

W jednym z najbardziej znanych ze swoich tekstów - utworze Niech żyje bal - Agnieszka Osiecka wykorzystuje motyw tańca jako metaforę życia. Metaforę, która pozwala pokazać określoną wizję ludzkiej egzystencji, jej sens i preferowany przez podmiot piosenki sposób radzenia sobie z własną pozycją w świecie. Taniec w twórczości Osieckiej pojawia się w wielu odsłonach - jako wspomnienie (Mój pierwszy bal), forma nawiązania kontaktu i wyrażenia emocji (Bossa nova do poduszki). Najszerzej wykorzystany zostaje jednak właśnie jako źródło metafor, często egzystencjalnych, dzięki którym jest środkiem służącym mówieniu o ludzkim życiu i jego wymiarach.

Osiecka za pomocą poetyckich obrazów tańca mówi o sprawach ważnych, filozoficznych, egzystencjalnych. Doświadczenie tańca było bowiem autorce bliskie, o czym wspomina wielokrotnie w swoich dziennikach. Tworzyło ważny aspekt jej relacji międzyludzkich („Mia- 
łam wtedy jedno marzenie: żeby tańczyć z Januszem”11), formę zaangażowania się w inną od codziennej rzeczywistość („No cóż - jak zabawa, to taniec. A tam był tłok. A miałam ochotę szaleć!!!”2), wreszcie - czynnik kształtujący jej tożsamość: „A gdyby ostatecznie ktoś się mnie spytał, co ja najbardziej lubię robić, odpowiedziałabym bez wahania: »Przyjemnie potańczyć «" 3 . Nawet w tych autobiograficznych rozważaniach Osieckiej zdarza się posłużyć motywem tańca w charakterze metaforycznym: „Coś mi szaleje w duszy i tańczy aż do gardła, i śpiewa!"4; „Obie z Jadzią Ratajczyk mamy dziś takie roztańczone, rozśpiewane dusze” 5 .

Dzięki temu, że Osiecka operuje szczególną formą wyrazu - piosenką - tworząc we współpracy z autorami muzyki i wykonawcami dzieło wielowymiarowe, taniec uobecniać się może na różnych płaszczyznach utworów. Jaką formę przybiera owa obecność motywów tanecznych? Podobnie jak Andrzej Hejmej klasyfikuje różne formy splatania się muzyki z literaturą (takie jak tematyzowanie muzyki na poziomie semantycznym czy przekładanie jej prawideł na poziom formalny tekstu) ${ }^{6}$, tak Andrzej Zawadzki zauważa, że w kwestii związków tańca i tekstu pisanego dostrzec można taniec jako temat w warstwie semantycznej oraz taniec (najczęściej konkretnego gatunku) jako inspirację struktury utworu? ${ }^{7}$. Według Eugeniusza Czaplejewicza taniec może dostarczać literaturze:

1) przebogaty zasób tematów, motywów i obrazów,

2) repertuar środków szczególnej ekspresji artystycznej o wyjątkowej intensywności,

3) silny czynnik formotwórczy, działający skutecznie w wielu planach poetyki,

4) dynamiczny składnik znaczeniotwórczy, konstytuujący sens artystyczny8.

Analizując utwory Osieckiej, należy jednak pamiętać o dodatkowym, piosenkowym wymiarze jej projektów - taniec może tu być zatem nie tylko tematem tekstu i podstawą jego literackiej formy, lecz także wpisywać się w utwór na poziomie muzyki czy nawet samego sposobu jej wykonywania. W wypadku twórczości Osieckiej piosenka jako całość tworzy summę pracy twórczej kilku osób, w tym kompozytora muzyki i wykonawcy. Sam jednak gest sięgnięcia poetki po formę piosenkową jest decyzją wykorzystania nie tylko języka literatury, lecz i całego spektrum środków oddziaływania na odbiorcę. Wiktoria Siedlecka na łamach pisma „Piosenka” zauważa znaczenie aspektu wykonawczego w całym procesie percepcji piosenki. Skupia się co prawda na zjawisku wykonań autorskich, jednak jej obserwacje pokazują uniwersalne elementy znaczące $w$ dziele, jakim jest każda wokalna realizacja utworu słowno-muzycznego: „Autorskie wykonanie jakby przypieczętowuje to zrośnięcie dzieła i twórcy: słowo pada z ust swego autora i ma nadaną przez niego nie tylko wartość muzyczną, ale i emocjonalną" ${ }^{9}$. Siedlecka zwraca też uwagę na takie aspekty wykonania, jak oddechy, mimika, kontakt z odbiorcą - „śpiewne teksty bardów nasycone są życiem wręcz dosłownie"10 - stwierdza.

\footnotetext{
1 A. Osiecka, Dzienniki i zapiski, t. 3, red. K. Felberg-Sendecka, Warszawa 2015, s. 110.

2 Ibidem, s. 375.

3 Ibidem, s. 75.

4 Ibidem, s. 110.

5 Ibidem.

6 Zob. A. Hejmej, Muzyczność dzieła literackiego, Toruń 2012.

7 Zob. A. Zawadzki, W tańcu tylko wypowiadać potrafię najwyższych rzeczy przenośnie: metafora tańca w tradycji modernistycznej, „Pamiętnik Literacki” 89, 1998, z. 3, s. 31-63.

8 E. Czaplejewicz, Słowo wstępne, [w:] Taniec i literatura, red. E. Czaplejewicz, J. Potkański, Puł-

9 W. Siedlecka, Bard - rodowód i współczesne znaczenie terminu, „Piosenka” 2007, nr 1, s. 7.

10 Ibidem.
} tusk-Warszawa 2002, s. 10. 
Językiem poezji Osiecka mówi o języku tańca - a więc języku gestów, ciała. Jednocześnie sytuacja percepcji piosenki jako utworu słowno-muzycznego powoduje, że do odbiorcy dociera także trzeci język - muzyczny, na który składają się czynniki takie, jak rytm, melodia, dynamika, głośność. Można mówić także o czwartym języku: interpretacji wykonawczej, w ramach której do przekazu dodany zostaje tembr głosu, określone emocje wpisywane w wyśpiewywanie konkretnych fraz, a także mimika i gesty wokalistki (te ostatnie aspekty zanikają, gdy percepcja odbywa się za pośrednictwem nagrania samego dźwięku). Kiedy Osiecka w tak wielowymiarowy konstrukt wpisuje temat taneczny, odwołuje się do jeszcze jednej sztuki, jeszcze jednej formy przekazu treści i emocji. Formy, która opiera się przede wszystkim na dwóch językach: muzycznym oraz choreograficznym, przy czym ten drugi nie zasadza się jedynie na sekwencji określonych ruchów i póz, lecz też na indywidualnym sposobie ich wykonywania, zależnym od temperamentu, emocji i sposobu poruszania się tancerza. Można zatem zauważyć istotne obszary wspólne dla języka piosenki oraz języka tańca: ów obszar to muzyczne oraz interpretacyjne (związane z osobowością i emocjami) środki wyrazu. Janusz Sławiński stwierdza, że związek dzieła literackiego i tekstu literaturoznawczego, w odróżnieniu od relacji tekstu dotyczącego dzieła malarskiego z tym dziełem, zasadza się na wspólnym języku. Malarz i krytyk wyrażają swe myśli za pomocą odmiennego systemu znaków, literat zaś i literaturoznawca - tożsamego. W piosence eksploatującej motywy taneczne język mówienia o tańcu przybliża się do języka tańca, co pozwala opisywać doświadczenie tańczenia oraz wywołać podobne emocje, wciągając w pewnym stopniu odbiorcę w podobne do tematyzowanego w utworze przeżycie. Język piosenki pozwala być bliżej właściwych tańcowi uczuć. Na wspólne cechy czynności śpiewania i czynności tańczenia wskazuje chociażby Friedrich Nietzsche: „śpiewając i tańcząc uzewnętrznia się człowiek jako członek wyższej, bardziej idealnej wspólnoty: oduczył się chodzić i mówić"11. Osiecka wprowadza zatem odbiorcę w przeżywanie signifiant swoich metafor, by następnie ukazać ich signifié i zaprosić do głębszej refleksji.

W piosenkach Sopockie bolero oraz To nasze ostatnie bolero taniec pojawia się w tekście dyskretnie, warunkuje jednak sytuację liryczną, a przez specyfikę konkretnie nazwanego, niosącego określony ładunek kulturowy tańca daje istotny klucz interpretacyjny. Przydatnym kontekstem staje się tu charakterystyka samego bolera. Jest to bowiem taniec niezwykle zmysłowy, oparty na balansie ciała, przybliżeniach i oddaleniach, wychyleniach i powrotach. Ten właśnie ruch Osiecka czyni podstawą tekstu piosenki Sopockie bolero, wpisując w utwór dynamikę balansu. Pojawia się ona w warstwie semantycznej jako balans między indywidualizmem a relacją:

Na szklanki pustym dnie obejrzę stary film

O ludziach, co we mgle, o czasie, który był.

A tulił nas jak port, jak fort lirycznych band

Elegant, birbant, lord, sopocki Hotel Grand ${ }^{12}$.

Kobieta mówiąca w utworze wypowiada się na przemian to w liczbie pojedynczej, to w liczbie mnogiej. W swoistym strumieniu świadomości przeskakuje między teraźniejszą samotnością a przeszłym związkiem.

Motyw inspirowany krokiem bolera pojawia się też na innym poziomie semantycznym - podmiot balansuje między byciem w Sopocie a byciem poza:

11 F. Nietzsche, Pisma pozostałe, przeł. B. Baran, t. 1, Kraków 1993, s. 55.

12 A. Osiecka, Sopockie bolero, https://bibliotekapiosenki.pl/utwory/Sopockie_bolero/tekst (dostęp: 16.02.2021).

Dziennikarstwo i Media 15, 2021

(C) for this edition by CNS 
Adieu Zatoko Snów, good bye Riwiero Marzeń

Za rok zobaczę znów mój stolik w coctail barze ${ }^{13}$.

W obu płaszczyznach inspiracje taneczne realizują się także rytmicznym powracaniem. Poetyka piosenki splata się w ten sposób z „poetyką” choreografii tanecznej.

Tekst To nasze ostatnie bolero eksploatuje natomiast motyw tańca jako ucieczki, jako formy chwilowego, bardzo mocnego zaangażowania emocji i myśli. Bolero rozumiane jest tu jako styl zmysłowy i intensywnie zbliżający do siebie dwoje tancerzy. Główną pozycją, jaką autorka przenosi z poziomu choreograficznego na poetycki, będzie tu wtulenie się w siebie dwojga ludzi:

\section{Może jutro dopiero \\ Poznasz nędzę tych słów \\ Ale dzisiaj mnie porwij \\ Dzisiaj upij mnie znów \\ Dzisiaj tul mnie, tul mnie tak \\ Żeby tchu nam było brak ${ }^{14}$.}

Wtulenie ukazane zostaje jako pozycja angażująca, pozwalająca na odcięcie się od świata zewnętrznego. W ten sposób taniec w piosence To nasze ostatnie bolero wpisuje się w utartą już symbolikę "ostatniego tańca”, tańca zamykającego pewien etap, odcinającego od przeszłości i przyszłości, a zatem rozgrywającego się w swoistym czasoprzestrzennym zawieszeniu. Z takim tańcem - choć w zupełnie innym kontekście - mamy do czynienia w Weselu Stanisława Wyspiańskiego. Chocholi taniec wyrywa uczestników z ich zajęć i problemów, jest tańcem zapomnienia, tańcem poza czasem, poza przyczynami i skutkami.

W utworze Osieckiej owo zawieszenie poza przyczynami i skutkami, poza przeszłością i przyszłością zostaje zaakcentowane przez przeciwstawienie: „Może jutro dopiero / Poznasz nędzę tych słów / Ale dzisiaj mnie porwij"15. Jutro jawi się jako niepoznane, niepewne - a przez to mniej istotne niż odbywający się tu i teraz taniec. Jutro jest niczyje, niezawłaszczone, teraźniejszy taniec zaś - wyraźnie „nasz”, „wierny tobie i mnie” 16 , a zatem podporządkowany podmiotowi i adresatowi. W przeciwieństwie do chocholego tańca "nasze ostatnie bolero" jest własne, kontrolowane, należy do podmiotu i adresata i daje się dostosować do zadania, jakie ma wypełnić, a którym jest przyniesienie pożądanego zapomnienia.

Taniec jako metafora oderwania od realizmu codziennego życia obecny jest nie tylko w samej sytuacji lirycznej, lecz także w przytaczanej retrospekcji:

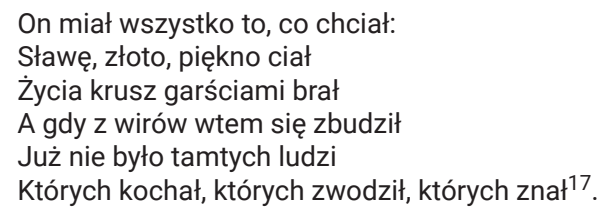

Doświadczenie zaangażowania się w coś, co wyrywa z porządku codzienności i jej praw, okazuje się co prawda pożądane przez podmiot, ale zarazem niebezpieczne. Jednocześnie przybiera nową formę wyrażania w tanecznym języku - poza wtuleniem jest to

13 Ibidem.

14 A. Osiecka, To nasze ostatnie bolero, https://bibliotekapiosenki.pl/utwory/To_nasze_ostatnie_ bolero/tekst (dostęp: 21.02.2021).

15 Ibidem.

16 Ibidem.

17 Ibidem.

Dziennikarstwo i Media 15, 2021

(C) for this edition by CNS 
również wirowanie. Wir jako metafora wpisuje w utwór dynamikę, która umożliwia rozszerzanie jego znaczeń. Zatacza bowiem coraz większe kręgi:

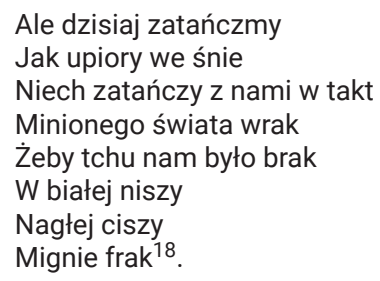

Taniec podmiotu i adresata staje się siłą napędową wydarzenia uniwersalnego. Rozszerzający się wir, dotąd pochłaniający jedynie racjonalne myśli dwojga tancerzy, teraz wciągnąć ma również całą przeszłość. Jednocześnie nie przestaje być procesem kontrolowanym przez podmiot i adresata - po raz kolejny powtórzony zostaje refren „To nasze ostatnie bolero"19 - taniec działa niejako na ich usługach, spełniając zadanie oczyszczenia ich świata. Powtarzalność refrenu, tak charakterystyczna dla poetyki piosenki, pozwala podkreślić ową zależność formy i sposobu oddziaływania tańca od jego prowodyrów. Kolejne powtórzenia tego fragmentu tekstu to kolejne znaczniki zawłaszczenia choreografii, a co za tym idzie - również przeszłości, pochłanianej przez czynność tańczenia.

W obu utworach bolero jest metaforą swoistego igrania z przeszłością. Metafory te opierają się na choreografii tańca: balansie wywoływanym przenoszeniem ciężaru ciała z nogi na nogę oraz wtuleniu się w partnera i wirowaniu. Określona dynamika kroków zostaje wpisana w sposób myślenia o relacji człowieka z jego przeszłością i przyszłością, a zarazem jest konceptem poetyckim tekstów piosenek. Ruch, nad którym panuje jego wykonawca, to figura panowania nad sposobem istnienia przeszłości w teraźniejszym świecie człowieka. Skoro tancerz decyduje o balansie ciała, pozie, bliskości z partnerem - może, w wymiarze przenośnym, decydować o bliskości wspomnień, zaangażowaniu w nie i ich wpływie na własne życie. Obie piosenki za sprawą tanecznych metafor stają się zatem manifestacją władzy nad siłą przeszłości, możności izolacji od niej, sprawczości ludzkiego decydowania o tym, w jaki sposób ta siła zaznacza swą obecność w biegu życia.

Wir zapomnienia, o którym mowa w utworze To nasze ostatnie bolero, w nieco innej realizacji pojawia się w piosence Pijmy wino za kolegów. Taniec nie jest w niej dominującym motywem, jednak jest jedną z metafor składających się na zachętę do izolacji tym razem nie od przeszłości, lecz od teraźniejszości i przyszłości, nieodłącznie związanej z przemijaniem. Taniec okazuje się tu przywilejem wybranych, tych, którzy mają „ciepłą strawę i kąt, / opinię jak łza [...]"20, a więc wpisują się w przyjętą społecznie wizję dobrobytu, traktowaną przez podmiot utworu z ironią i dystansem. Ów dystans wobec wszystkiego, co składa się na codzienność, tworzy sytuację izolacji w swoistym zawieszeniu. Izolacji wspólnotowej, albowiem w owym czasoprzestrzennym zawieszeniu znajduje się grupa identyfikująca się w piosence jako „my”. W izolację tę wprowadza przede wszystkim czynność picia alkoholu - to ona pozwala przekroczyć symboliczną granicę między zwyczajnym biegiem życia a chwilowym zapomnieniem. Wzmocnieniem tego poetyckiego obrazu ludzi wkraczających w oddzieloną od przemijania rzeczywistość staje się taniec:

\footnotetext{
18 Ibidem.

19 Ibidem.

20 Zob. A. Osiecka, Pijmy wino za kolegów, https://bibliotekapiosenki.pl/utwory/Pijmy_wino_za_ kolegow (dostęp: 18.04.2021).
}

Dziennikarstwo i Media 15, 2021

(C) for this edition by CNS 
Idźmy w taniec malowany na szkle,

bo żona ma żal, do tańca się rwie 21 .

Wejście w rzeczywistość tańca jawi się jako jeszcze głębsze zdystansowanie się wobec świata, jeszcze głębsze zanurzenie we wspólnotowym zapomnieniu. Tak jak w To nasze ostatnie bolero przeważa tu tryb rozkazujący, czasowniki wyrażające zachętę i mocne pragnienie. Owo wejście, rozpoczęcie tańca, nie ma znamion przypadkowości, ma natomiast być wynikającą z własnych chęci podmiotu decyzją zaangażowania się w ruch. Genevieve Stebbins, zajmując się taneczną ekspresją, zwraca uwagę na wyjątkowość momentu wkraczania w ruch. Według niej przed ruchem musi nastąpić faza rozluźnienia, czyli „oddania ciała ciążeniu, umysłu - naturze" ${ }^{22}$. W tym świetle wkraczanie w rzeczywistość tańca jest dobrowolnym zdystansowaniem się wobec świata ludzkiej dominacji.

Podmiot obnaża jednak iluzję tego zapomnienia - ironicznie nazywa taniec "malowanym na szkle”, a więc przesłaniającym codzienność złudzeniami. Piosenka kończy się gorzkim zrównaniem pijących i tańczących z resztą społeczeństwa we wspólnej perspektywie nieuniknionego przemijania:

Pijmy wino za kolegów do dna,

bo oni - to my, a my - to już mgła ${ }^{23}$.

Motyw tańca zastosowany tu przez Osiecką okazuje się zatem swoistym odwróceniem danse macabre - za pomocą tańca podmiot i jego towarzysze usiłują wyrwać się z powszechnej konieczności przemijania, jednak ich starania okazują się bezskuteczne.

Tytuł piosenki Niech żyje bal nie odwołuje się do żadnego konkretnego stylu tanecznego, jednak utwór funkcjonował niegdyś także pod tytułami Walczyk czy Walc a-moll ${ }^{24}$. Tekst rozpoczyna natomiast charakterystyczne wyliczenie:

fantango, bolero, bebop,

manna, hosanna, różaniec i taniec,

i jazda, i basta, i stop ${ }^{25}$.

To oryginalne, a przy tym bardzo rytmiczne i dynamiczne otwarcie tekstu zawiera trzy nazwy stylów tanecznych: fandango, bolero i bebop. Pierwszy z nich to hiszpański taniec o żywiołowym charakterze:

Wszystko jest życiem i ruchem w fandango - krok jego, to sama lekkość, wdzięk i giętkość; w ruchach maluje się charakter Hiszpanów, wyniosłość, duma i miłość; rozkoszne grupy i pozy, spadki i charakter muzyki, wszystko to upaja patrzących Hiszpanów i w zachwycenie ich wprawia ${ }^{26}$.

Osiecka wymienia także tak chętnie eksploatowane przez nią bolero, które w porównaniu do fandanga „jest tańcem szlachetniejszym i skromniejszym; jest to miłość sfery bardziej duchowej. Bolera śpiewane z towarzyszeniem gitary nazywają się seguidillas boleras" 27.

21 Ibidem.

22 G. Stebbins, The Delsarte System of Expression, New York 1902, s. 401; cyt. za: Historia ciała, t. 3. Różne spojrzenia. Wiek XX, red. J.J. Courtine, Gdańsk 2020.

23 Ibidem.

24 Zob. A. Osiecka, Niech żyje bal, https://bibliotekapiosenki.pl/utwory/Niech_zyje_bal (dostęp: 25.02.2021).

25 Ibidem.

26 K. Czerniawski, Charakterystyka tańców, Warszawa 1847, s. 18.

27 Ibidem.

Dziennikarstwo i Media 15, 2021

(C) for this edition by CNS 
Bebop to natomiast styl w jazzie, szczególny pod tym względem, iż u jego początku leży pragnienie upowszechnienia gatunku muzycznego, który na pewien czas nabrał hermetycznego charakteru, stając się dostępnym tylko dla bogatych klientów klubów ${ }^{28}$ :

Dopiero w latach 40-tych grupy awangardowych muzyków walcząc ze sztywnym gorsetem komercji i powielania muzycznych szablonów, zaczęły eksperymentować z formą, wynajdując "bebop” a później „cool” oraz "hard bop”. Nurty, których daleko posunięta innowacyjność jest równie niezwykła na obszarze stricte muzycznym, jak i obyczajowym ich wyznawców29.

Wybierając te trzy style, Osiecka nadaje metaforycznemu tańcowi określonego charakteru. Sięga po dynamikę ruchów żywych, a zarazem różnorodnych - od hiszpańskiej zmysłowości po jazz. W ten sposób tytułowy bal okazuje się uniwersalnym, powszechnym, dostępnym zarówno dla połączonych zmysłowymi relacjami par, jak i samotnych jednostek, dla bogatych i biednych. Nawiązanie do bebopu jako rozwiązania socjologicznego, formy upowszechniania tańca wśród mas, podkreśla, że bal ma być tu wydarzeniem na miarę średniowiecznego danse macabre - jednoczącym ludzkość jako ogół w doświadczeniu zmierzenia się z tym, co ostateczne. Egzystencjalny wymiar tanecznej metafory zapowiada już pierwszy wers tekstu: „Życie, kochanie, trwa tyle co taniec”30.

Wyliczenie stylów tanecznych znajduje kontynuację w kolejnych zbiorach pojęć. W szeregu „manna, hosanna, różaniec i taniec"31 podmiot ustawia niejako na równi taniec i słowa ściśle związane ze sferą sacrum. Dokonuje tym samym uwznioślenia czynności tańczenia i kojarzy ją ze swoistą formą modlitwy, a co za tym idzie - mierzenia się z perspektywą śmierci i wieczności.

Szereg „i jazda, i basta, i stop"32 to natomiast pełen dynamiki zapis szybkiego ruchu i nagłego zatrzymania - a zatem tekstowa realizacja tanecznego kroku. Podmiot wprowadza w ten sposób odbiorcę w swoje uczestnictwo w tańcu, pokazuje go niejako od środka. Nie słuchamy już więc jedynie o tańcu jako wzniosłej metaforze, ale i o jego praktycznym wymiarze, opartym na sekwencji określonych ruchów.

Ukazana owym krótkim wyliczeniem szybkość i dynamika tańca znajduje kontynuację w kolejnych nawiązaniach do danse macabre. Osiecka także tutaj - jak w piosence To nasze ostatnie bolero - sięga po wirowanie jako proces zwiększający stopniowo swój zasięg. Buduje świat balu przez narastanie, do tańczących dołączają kolejni:

Chłopo-robotnik i boa-grzechotnik

z niebytu wynurza się fal,

widzi swą mamę i tatę, i żonkę

i rusza, wyrusza - na bal ${ }^{33}$.

Przypadkowość wymienionych przykładów tancerzy - „chłopo-robotnik”, „boa-grzechotnik" - uniwersalizuje udział w balu, czyniąc go wydarzeniem dla każdego bez wyjątku. Jednocześnie poetycki obraz balu jest kompozycją otwartą także na odbiorcę - powtarzana jest fraza „jeszcze tańczą i drzwi są otwarte" ${ }^{4}$, pojawiają się także formy gramatyczne budu-

\section{Zob. M. Grzegorzewski, Socjologiczne oblicze jazzu, „Pisma Humanistyczne” 2001, nr 3, s. 245-}

246.
29 Ibidem, s. 246.
30 A. Osiecka, Niech żyje bal.
31 Ibidem.
32 Ibidem.
33 Ibidem.
34 Ibidem.

Dziennikarstwo i Media 15, 2021

(C) for this edition by CNS 


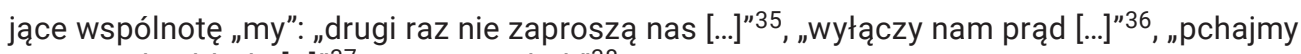
więc taczki obłędu [...]”37, „raz mamy bal!"38.

Motyw danse macabre, narastający w tekście, zostaje wreszcie nazwany wprost, jednak w groteskowej, ironicznej stylistyce:

Sucha kostucha, ta Miss Wykidajło

wyłączy nam prąd w środku dnia,

pchajmy więc taczki obłędu jak Byron,

bo raz mamy bal! ${ }^{39}$

Podmiot utworu eksploatuje zatem najpierw popularny motyw, a następnie dystansuje się wobec niego, dekonstruując budowane na początku piosenki sacrum. Jarosław Barański, broniąc swej tezy o kulturowym przedawnieniu się danse macabre w związku ze zmianą rozumienia opozycji święte-codzienne, pisze: „Taniec Śmierci jako wielowiekowa figura kulturowej wyobraźni zamiera wraz ze zmysłowością współczesnej wyobraźni tam, gdzie nauka i wiedza proponuje własne figury rozumienia i odczuwania świata człowieka"40. We współczesnym mierzeniu się ze śmiercią człowiek - podmiot utworu Osieckiej - czuje się mimo wszystko zwycięzcą, choć ma świadomość, że jego wygrana trwa jedynie w teraźniejszości. Stąd potrzeba łapania chwili, w której „jeszcze tańczą [...]"41. Taniec w piosence Niech żyje bal okazuje się zatem nie tańcem śmierci, lecz raczej tańcem chwili, tańcem przedśmiertnego carpe diem. W tej perspektywie wymienione na początku utworu style taneczne ewokują dynamikę tańca życia, kontrastowanego z tradycyjnym tańcem śmierci. Podobnie jak w tekście To nasze ostatnie bolero Osiecka chwyta tu chwilę naznaczoną doświadczeniem pewnego końca, czegoś ostatniego, zamykającego. Taką właśnie chwilę wpisuje w metaforę tańca, by ukazać emocje i myśli towarzyszące przeżyciu owej „ostatniości”.

Sposobem skłonienia odbiorcy do emocjonalnego przeżycia warstwy znaczącej budowanych metafor - tym samym do zaangażowania się w refleksję wokół ich warstwy znaczonej - jest wykorzystanie piosenkowej relacji słowa z muzyką. Reguły rządzące tekstem piosenkowym na poziomie literackim przywodzą na myśl wiersz meliczny:

Wiersz meliczny ma dwie treści: literacką i muzyczną. Zlewają się one ze sobą, a symbioza polega na zachowaniu obydwóch, jakkolwiek zwykle jedna z nich jest czynnikiem rządzącym. Dla zachowania treści literackiej, poetyckiej konieczne jest utrzymanie pewnych norm językowych ${ }^{42}$.

Tekst utworu To nasze ostatnie bolero został pomyślany tak, by pod względem formalnym ułatwiał charakterystyczne dla rytmu bolero wykonanie - wersy i całostki znaczeniowe są krótkie niczym takty w melodii towarzyszącej temu tańcowi, umożliwiają częste urywanie śpiewu, wykrzykiwanie fraz, nadawanie piosence charakterystycznej dynamiki. Przyspieszenie refrenu (także zaznaczone w tekście krótszymi wersami) pozwala na budowanie wrażenia „porywania” słuchacza do tańca, co koresponduje z treścią tanecznej przenośni.

Bardzo podobny zabieg Osiecka stosuje w piosence Niech żyje bal. Co prawda warstwą brzmieniową nie nawiązuje do wymienianych stylów tanecznych, ale sięga po wyliczenia,

35 Ibidem.

36 Ibidem.

37 Ibidem.

38 Ibidem.

39 Ibidem.

40 J. Barański, Motyw tańca śmierci: o kulturowej erozji figury wyobraźni, „Medycyna Nowożytna” 6, 1999, z. 1, s. 58.

41 A. Osiecka, Niech żyje bal.

42 M. Dłuska, Wiersz meliczny - wiersz ludowy, „Pamiętnik Literacki” 45, 1954, z. 2, s. 473-474.

Dziennikarstwo i Media 15, 2021

(C) for this edition by CNS 
dzieli wypowiedź na małe segmenty. Język tej piosenki obfituje w wyraziste rymy, krótkie słowa, czasowniki w trybie rozkazującym. Pozwala to wykonawcy na częste zawieszanie głosu i tym samym budowanie napięcia i także rytmu odpowiadającego sekwencji kroków i zatrzymań w tańcu. Na poziomie znaczeniowym zabiegi te wzmacniają przekaz dotyczący przemijania i jednostkowości opisywanej chwili. W refrenie natomiast zwięzłe frazy Osieckiej zmuszają do wydłużania sylab, dzięki czemu warstwa brzmieniowa utworu przywodzi na myśl wirówkę i podobnie jak w wypadku bolera angażuje odbiorcę w przeżywanie - przynajmniej na poziomie wyobrażeniowym - tanecznego wiru. Ponownie słuchacz zostaje więc zaproszony do wyobrażenia sobie własnego udziału w dosłownej warstwie metafory.

Taniec w tekstach piosenek Osieckiej funkcjonuje zatem zarówno jako struktura figur i ruchów, jak i jako sposób przeżywania określonej sytuacji życiowej: balansowania między samotnością a relacją, przeszłością a przyszłością, zaangażowaniem w teraźniejszość a myśleniem o tym, co ostateczne. Taniec buduje swoiste zawieszenie w czasie i przestrzeni - w procesie tańczenia przestają obowiązywać i przyczyny, i skutki, i upływ czasu - co pozwala na pochwycenie chwili z jej emocjami i refleksjami. W każdym z wymienionych utworów Osiecka wykorzystuje szerokie możliwości, jakie daje forma piosenkowa - bawi się rytmicznością, powtórzeniami, czyni atut z faktu, że w piosence nie czytamy jedynie treści niesionych przez sam tekst, lecz całą sytuację wykonywania dzieła, kontakt wykonawcy z publicznością, muzykę.

Taniec - z różnorodnością ruchów i żywiołową dynamiką, która wyrywa z codziennego biegu wydarzeń - jest zatem rzeczywistością kumulującą emocje, swoistym laboratorium uczuć, wyizolowanych z kontekstów, w jakich się zrodziły. Realizowanie emocji przez choreografię, przekładanie ich na język ruchów pozwala na przeżycie ich w sposób zintensyfikowany. Osiecka w swych „tanecznych” tekstach prezentuje zatem odbiorcy kompilację emocji przetłumaczonych na języki gestów, ruchów, kroków oraz stylów tanecznych z przypisywaną im w kulturze charakterystyką. Czyni tym samym taniec metaforą rozmaitych sposobów przeżywania procesu radzenia sobie człowieka z własną pozycją w świecie i upływem czasu.

\section{Bibliografia}

Barański J., Motyw tańca śmierci: o kulturowej erozji figury wyobraźni, „Medycyna Nowożytna” 6, 1999, z. 1, s. $43-59$.

Czerniawski K., Charakterystyka tańców, Warszawa 1847.

Dłuska M., Wiersz meliczny - wiersz ludowy, „Pamiętnik Literacki” 45, 1954, z. 2, s. 473-474.

Grzegorzewski M., Socjologiczne oblicze jazzu, „Pisma Humanistyczne” 2001, nr 3, s. 235-248.

Hejmej A., Muzyczność dzieła literackiego, Toruń 2012.

Historia ciała, t. 3. Różne spojrzenia. Wiek XX, red. J.J. Courtine, Gdańsk 2020.

Nietzsche F., Pisma pozostałe, przeł. B. Baran, t. 1, Kraków 1993.

Osiecka A., Dzienniki i zapiski, t. 3, red. K. Felberg-Sendecka, Warszawa 2015.

Osiecka A., Niech żyje bal, https://bibliotekapiosenki.pl/utwory/Niech_zyje_bal (dostęp: 25.02.2021).

Osiecka A., Pijmy wino za kolegów, https://bibliotekapiosenki.pl/utwory/Pijmy_wino_za_kolegow (dostęp: 18.04.2021).

Osiecka A., Sopockie bolero, https://bibliotekapiosenki.pl/utwory/Sopockie_bolero/tekst (dostęp: 16.02. 2021).

Osiecka A., To nasze ostatnie bolero, https://bibliotekapiosenki.pl/utwory/To_nasze_ostatnie_bolero/tekst (dostęp: 21.02.2021).

Siedlecka W., Bard - rodowód i współczesne znaczenie terminu, „Piosenka” 2007, nr 1, s. 4-8.

Taniec i literatura, red. E. Czaplejewicz, J. Potkański, Pułtusk-Warszawa 2002.

Zawadzki A., W tańcu tylko wypowiadać potrafię najwyższych rzeczy przenośnie: metafora tańca w tradycji modernistycznej, „Pamiętnik Literacki” 89, 1998, z. 3, s. 31-63.

Dziennikarstwo i Media 15, 2021

(C) for this edition by CNS 